\title{
Assessing the competitiveness of Kazakhstan regions: creating an index
}

\author{
Aknur Zhidebekkyzy ${ }^{1, *}$, Rimma Sagiyeva ${ }^{1}$, Zhansaya Temerbulatova $^{1}$ \\ ${ }^{1}$ Al-Farabi Kazakh National University, al-Farabi Ave. 71, 050040 Almaty, Kazakhstan
}

\begin{abstract}
Today there is no single universally accepted method for assessing the competitiveness of the country's regions. For this reason, the research created a methodology for assessing competitiveness at the regional level for Kazakhstan. The three-factor model of Huggins for ranking the regions of Great Britain by the level of competitiveness was used as the basis, and then the model was expanded on the example of a study assessing the competitiveness of the regions of the European Union countries. All data for assessing the competitiveness of the regions of Kazakhstan were collected from the official website of the Committee on Statistics of the Ministry of National Economy of the Republic of Kazakhstan. In the article, 14 regions and 2 cities of republican significance were ranked in terms of competitiveness. As a result, the most competitive regions of Kazakhstan were Almaty city, Atyrau region and Nur-Sultan city, the worst indicator was found for the North Kazakhstan and Zhambyl regions.
\end{abstract}

\section{Introduction}

Today, one of the highest priorities facing each state is increasing national competitiveness. National competitiveness reflects the country's ability to achieve high rates of economic growth and maintain it in the long run, control the efficient use of resources and compete in the international arena. For increasing the level of national competitiveness, it is important to understand its formation structure. Figure 1 shows a hierarchy of concepts of competitiveness.

A competitive product is a product that is attractive to the buyer in comparison with other products of a similar type and purpose due to the better conformity of its quality and cost characteristics to the requirements of this market and consumer ratings. The release of just such a product, superior to competitors, forms the enterprise competitiveness. A competitive enterprise with its high performance indicators provides comparative or absolute advantages for the industry in which it operates. An industry with a comparative or absolute advantage, due to the demand in the domestic and international markets, increases the gross regional product. A steady growth rate of gross regional product and, as a result, an increase in the standard of living of the population forms the competitiveness of the region. Regions that

* Corresponding author: aknur.zh@gmail.com 
have achieved high rates of socio-economic development are able to create competitiveness at the national level.

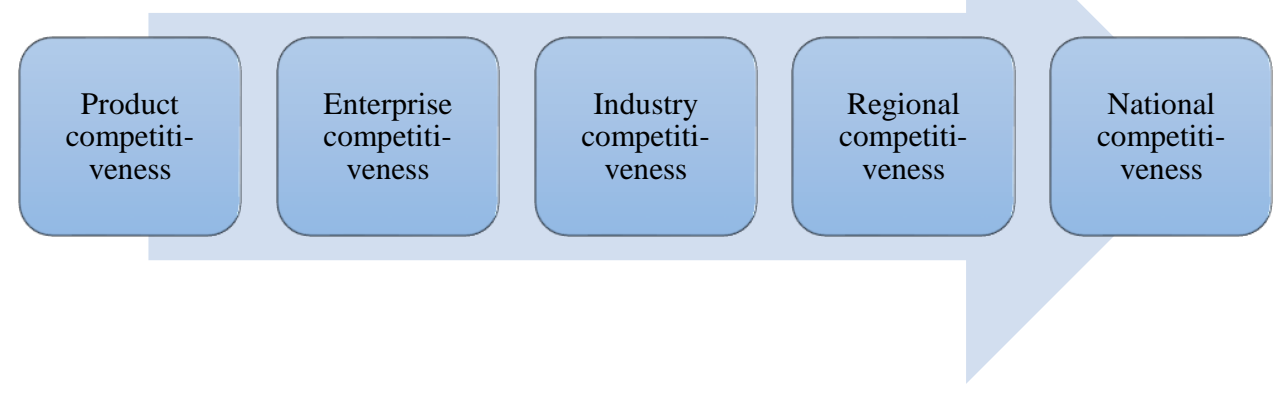

Fig. 1. The hierarchy of concepts of competitiveness

Despite the large amount of economic literature on the regional economy, the concept of "regional competitiveness" is poorly understood. There is no single methodology, a set of indicators and criteria for assessing the level of regional competitiveness as for national competitiveness. Analysis of the competitiveness of the country's regions is very important, as the regions create conditions in domestic and foreign markets.

This article is aimed at assessing the competitiveness of Kazakhstan at the regional level in a comparative perspective. The purpose of this study is to create a regional competitiveness index of Kazakhstan. 14 regions and 2 cities of republican significance ranked in accordance with their competitive position. In addition, this index allows us to examine in detail the indicators that contribute to the competitiveness of the region.

\section{Literature review}

An analysis of the theoretical and methodological concepts of regional competitiveness provides a wide range of points of view of many authors. In some aspects, these points of view overlap; authors often come to the same or similar conclusions.

In a study, Birnie et al. note the importance and complexity of measuring regional competitiveness. Since the bulk of research on this topic is aimed at assessing the competitiveness of the national economy, however, indicators and measures identified at the national level cannot be applied at the regional level. The authors examine the regional competitiveness of Northern Ireland in the context of increasing comparative productivity [1].

Kitson et al. consider regional competitiveness as the aggregate competitiveness of firms [2], Wokoun et al. as a derivative of macroeconomic competitiveness [3]. The European Commission defines regional competitiveness as the ability of regions to generate a relatively high level of income and employment [4].

Some authors attribute regional competitiveness to economic growth dynamics. According to the author's findings, important indicators are unemployment rate and GRP per capita [5, 6]. Dijkstra \& Annoni regard that regional competitiveness is manifested by the region's ability to provide firms and residents with attractive and sustainable living and working conditions [7]. Koisova et al. use DEA models to measure the effectiveness with 
which states convert input to output. This method allows determining the level of rational use of basic resources to achieve a high level of competitiveness, this, according to the authors, is the key to a high level of income of residents of the region [8].

Boschma emphasizes the importance of non-economic factors, such as social, cultural and institutional, in the formation of the region's competitiveness [9]. In turn, Kresl \& Ietri distinguish two types of factors of regional competitiveness: 1. economic factors, which include production factors, infrastructure, and economic structure; 2. strategic factors, which include the effectiveness of governance, development strategy, public-private partnerships and the ability of authorities to adapt to changing external environment [10].

Assessment of the region's competitiveness can be based on determining the level of socio-economic development and investment attractiveness of the regions, expert assessment of determining the rating of the region.

In a study by Holis et al. an alternative method for analyzing competitiveness at the mesoscale is proposed. Based on interviews with experts, five key indicators were identified that determine the competitiveness of the region: labor and human resources; productive business environment; infrastructure; natural resources and the environment; banking and financial institutions. According to the authors, a well-formed concept of the development of regional competitiveness can become a catalyst and factor in the development of regional specialization and interaction between regions in the era of economic globalization [11]. Regional specialization is determined using the competitive advantage index proposed by B. Balassa. Temerbulatova et al. evaluate industries with revealed competitive advantage for Kazakhstan and the EAEU countries. The emphasis on the development of identified industries in the concept of regional development helps to increase competitiveness both at the mesoscale and at the national level [12].

Huggins developed the index of competitiveness of the regions of Great Britain. This index fills the gap in the study of competitiveness, since existing analyzes on this issue tend to consider competitive factors separately and ignore the need for a combined structure of interrelated and interdependent factors. The Huggins index is built in the form of a model based on three main factors that conceptually determine competitiveness: input - output outcome. The Huggins Competitiveness Index is a dynamic tool for measuring regional competitiveness. It was used on British territory, but if changed, it can be applied in other countries [13].

In accordance with the approach of Huggins, Bronisz et al. made a competitive rating of 16 regions of Poland. The study revealed that Poland is a country with growing regional inequality, which is an inevitable consequence of the process of transformation and economic growth. To solve this problem, it was proposed to revise the basis of the country's competitive advantage [14].

The AV Group consortium developed the Russian Regional Competitiveness Index, which is a comprehensive assessment of the actual ability of regions to compete for resources and markets. A systematic assessment of the competitiveness of regions was carried out according to the following development factors: markets (products and the size of the economy), institutions (state, private and public), human capital, innovation and information, natural resources, space and real capital, investment and financial capital [15].

Wokun et al. rank the regions of the European Union in terms of competitiveness. The proposed index consists of three categories: economic, social and environmental. Based on the results, the first 30 and last 30 regions were selected in accordance with their scores. These regions were further analyzed in terms of factors contributing to regional competitiveness [3]. 


\section{Methodology}

Based on the approaches specified in the previous section, a methodology was developed to assess the level of competitiveness of the regions of Kazakhstan. The three-factor model proposed by Huggins R. was taken as the basis [13]. Further, the quantitative assessment was adapted to the regions of Kazakhstan using the example of a study by Wokoun et al. [3]. Figure 2 shows a three-factor model for evaluating the competitiveness of regions proposed by Huggins.

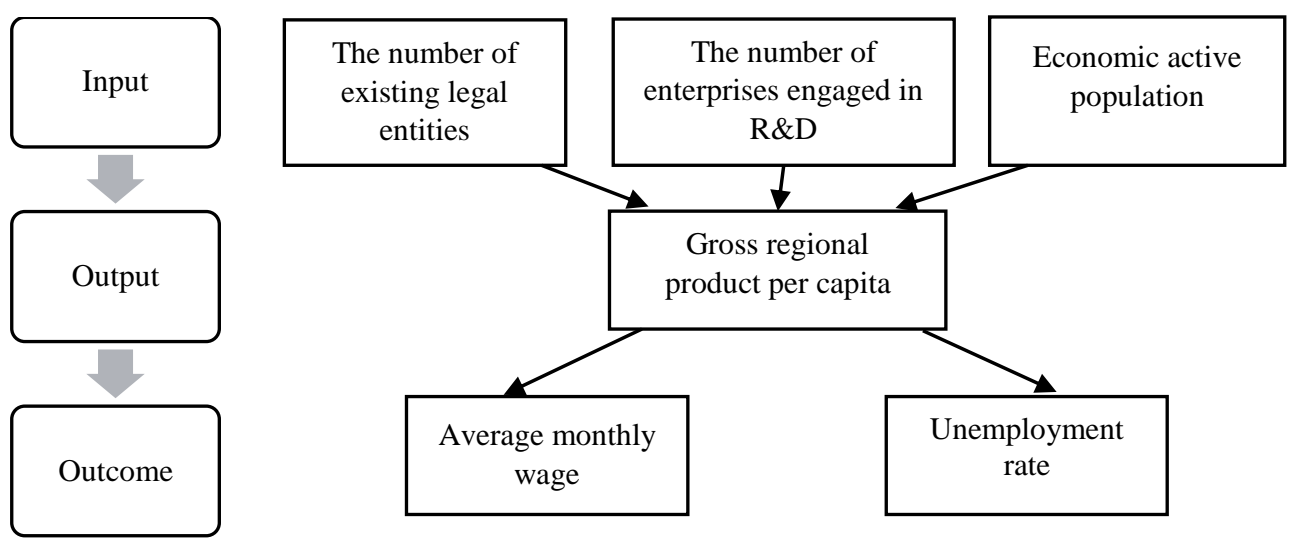

Fig. 2. Three-factor model for assessing the competitiveness of a region

According to the model for assessing the competitiveness of a region developed by Huggins, three groups of factors influence the ability of a region to compete: input - output outcome. Input factors include: the number of existing legal entities, the number of enterprises engaged in research and development and economic active population. These factors, in turn, form the output factor - the gross regional product per capita. Finally, the influence of all 4 factors is determined by the initial factors - the average monthly wage and unemployment rate in the region.

To assess the level of competitiveness of the region, this particular set of factors was chosen, since:

- GRP per capita is the most important indicator of the region's economic activity;

- average monthly wage reflects the level of wages of employed labor, and high wages are an indicator of competitiveness in the region, if they are also supported by high productivity;

- the number of existing legal entities is an indicator of the potential for sustainable economic growth through business development;

- the number of enterprises engaged in R\&D today is a key indicator of economic growth at all levels and provides the most important link between the competitiveness of enterprises and aggregate competitiveness at the national level;

- indicators of economic activity are an indicator of the presence of human capital in the region;

- unemployment rate is the main indicator evaluating the state of the labor market.

All data for assessing the competitiveness of the regions of Kazakhstan based on a threefactor model were collected from the official website of the Statistics Committee of the Ministry of National Economy of the Republic of Kazakhstan in the "Regions" section [16]. 
After collecting statistical data, the second stage of the study is the standardization of data for further calculations. The index created to assess regional competitiveness is based on a comparison of the values of one region with the most favorable value. The region that showed the best result is denoted as $100 \%$, the indicators of other regions are estimated as a percentage of the best region.

The third stage of the study is the determination of the specific gravity of each of the factors in assessing competitiveness. If the total weighting factor is 1 , then each of the three factors (input - output - outcome) receives the same specific gravity of 0.333 , since it is assumed that each of them equally affects the level of competitiveness of the region. Thus, we determine the specific weight when calculating each of the six indicators: the number of existing legal entities -0.111 ; the number of enterprises engaged in $R \& D-0.111$; economic active population -0.111 ; GRP per capita -0.333 ; average monthly wage -0.167 ; unemployment rate -0.167 .

The last stage is summarizing each indicator of the region and rank the regions according to the results, so get the regional competitiveness index (RCI).

Since the level of competitiveness depends on the dynamism of indicators, the assessment of the competitiveness of the regions of Kazakhstan was carried out over the past 5 years (2014-2018).

\section{Results and Discussion}

Table 1 shows the results of the competitiveness assessment of 14 regions and 2 cities of republican significance of Kazakhstan for 2018.

Table 1. Regional Competitiveness Index of Kazakhstan, 2018

\begin{tabular}{|c|c|c|c|c|c|c|c|c|}
\hline \multirow{2}{*}{ Indicators } & \multicolumn{2}{|c|}{ RCI } & \multicolumn{6}{|c|}{ Weight of each indicator } \\
\hline & 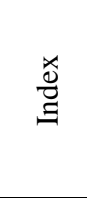 & 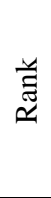 & 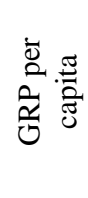 & 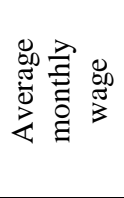 & 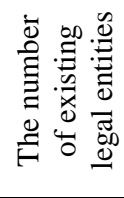 & 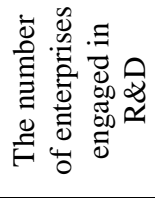 & 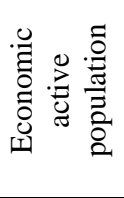 & 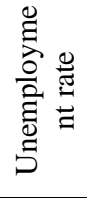 \\
\hline Almaty city & 80,05 & 1 & 22,93 & 12,05 & 11,10 & 11,10 & 8,71 & 14,16 \\
\hline Atyrau region & 70,71 & 2 & 33,30 & 16,70 & 1,32 & 0,85 & 2,93 & 15,61 \\
\hline $\begin{array}{l}\text { Nur-Sultan } \\
\text { city }\end{array}$ & 67,62 & 3 & 19,77 & 14,33 & 6,73 & 5,25 & 4,84 & 16,70 \\
\hline $\begin{array}{l}\text { Mangistau } \\
\text { region }\end{array}$ & 54,51 & 4 & 17,72 & 16,39 & 1,57 & 0,51 & 2,71 & 15,61 \\
\hline $\begin{array}{l}\text { Karaganda } \\
\text { region }\end{array}$ & 47,51 & 5 & 10,75 & 8,49 & 3,49 & 2,46 & 6,35 & 15,97 \\
\hline $\begin{array}{l}\text { East } \\
\text { Kazakhstan } \\
\text { region }\end{array}$ & 43,73 & 6 & 7,87 & 7,95 & 2,36 & 2,88 & 6,70 & 15,97 \\
\hline $\begin{array}{l}\text { West } \\
\text { Kazakhstan } \\
\text { region }\end{array}$ & 42,35 & 7 & 12,50 & 9,10 & 1,34 & 0,68 & 3,12 & 15,61 \\
\hline $\begin{array}{l}\text { Pavlodar } \\
\text { region }\end{array}$ & 41,92 & 8 & 10,91 & 8,31 & 1,93 & 0,93 & 3,86 & 15,97 \\
\hline $\begin{array}{l}\text { South } \\
\text { Kazakhstan } \\
\text { region* }\end{array}$ & 41,18 & 9 & 3,78 & 6,52 & 3,65 & 1,61 & 11,10 & 14,52 \\
\hline
\end{tabular}




\begin{tabular}{l|c|c|c|c|c|c|c|c}
\hline Aktobe region & 40,65 & 10 & 9,37 & 7,99 & 1,98 & 1,36 & 3,98 & 15,97 \\
\hline Almaty region & 40,26 & 11 & 4,25 & 6,97 & 2,16 & 0,93 & 9,62 & 16,34 \\
\hline $\begin{array}{l}\text { Kostanay } \\
\text { region }\end{array}$ & 38,17 & 12 & 7,18 & 7,36 & 1,67 & 1,19 & 4,80 & 15,97 \\
\hline $\begin{array}{l}\text { Akmola } \\
\text { region }\end{array}$ & 36,75 & 13 & 7,26 & 6,99 & 1,61 & 0,93 & 3,98 & 15,97 \\
\hline $\begin{array}{l}\text { Kyzylorda } \\
\text { region }\end{array}$ & 35,42 & 14 & 6,44 & 7,83 & 1,28 & 0,68 & 3,22 & 15,97 \\
\hline $\begin{array}{l}\text { North } \\
\text { Kazakhstan } \\
\text { region }\end{array}$ & 33,56 & 15 & 6,82 & 6,55 & 1,27 & 0,42 & 2,88 & 15,61 \\
\hline $\begin{array}{l}\text { Zhambyl } \\
\text { region }\end{array}$ & 33,32 & 16 & 4,15 & 6,35 & 1,36 & 0,93 & 4,92 & 15,61 \\
\hline
\end{tabular}

Note - compiled by the authors on the basis of calculations

* Shymkent city and the Turkestan region were evaluated together in the South Kazakhstan region due to insufficient data in order to consider the dynamics as two separate regions

According to the results of the study, the most competitive region of the Republic of Kazakhstan is Almaty city. In addition, this is not surprising, since Almaty city is a scientific, educational, cultural, historical, financial and economic center and the largest metropolis of Kazakhstan. In this index, it is immediately noticeable that Almaty is ahead of other regions in terms of the number of enterprises in general, and performing R\&D. Therefore, in 2018 in Almaty, the number of enterprises engaged in R\&D is 131 , which is 2.1 times more than in the city of Nur-Sultan and on average 10 times more than in other regions of Kazakhstan. In Almaty, other indicators are at a very high level, except for the unemployment rate compared to other regions. However, the unemployment rate in all regions varies from 4.6 to $5.3 \%$, for this reason, the proportion of the indicator of unemployment in each region differs slightly.

In second place in terms of competitiveness is Atyrau region, the largest oil production center in Kazakhstan. Such oil fields as Tengiz, Dauletaly, Zhana-Makat, Borkildakty are located in the region. The region leads in indicator gross regional product per capita, which is 9446.2 thousand tenge, while in the capital of Kazakhstan, Nur-Sultan is 5608.1 thousand tenge and in Almaty - 6505.7 thousand tenge. The consequence of this is the high average monthly salary of one employee - 264597 tenge, which is almost 2 times higher than the average monthly wage in Kazakhstan for 2018 is 148410 tenge.

In third place is the fastest growing city, the capital of Kazakhstan - Nur-Sultan city. In this region, the lowest unemployment rate, due to the rapid pace of development of the city, more and more new jobs are opened every year. According to other indicators, Nur-Sultan city does not lead, but it shows results at a high level.

The competitiveness level of the remaining regions is shown in Figure 3.

A high level of competitiveness is observed in 2 cities of republican significance (Almaty, Nur-Sultan) and in 2 western regions of Kazakhstan (Atyrau, Mangistau regions). These regions can be called drivers of economic growth in Kazakhstan. Atyrau and Mangistau regions have a competitive resource advantage in comparison with other regions; they achieve a high level of competitiveness due to oil production. Also in 2018, the regions signed a memorandum of cooperation. The purpose of signing the memorandum is the development of interregional cooperation and increasing the competitiveness of regions. The parties agreed to cooperate in the field of industry, small and medium-sized businesses, in the field of agriculture, health, ecology, and construction.

The competitiveness indicators of other industrial regions of Kazakhstan, such as East Kazakhstan, Karaganda, Pavlodar regions are at an average level. In addition, the average level of competitiveness is observed in the West Kazakhstan, Aktobe, South Kazakhstan and 


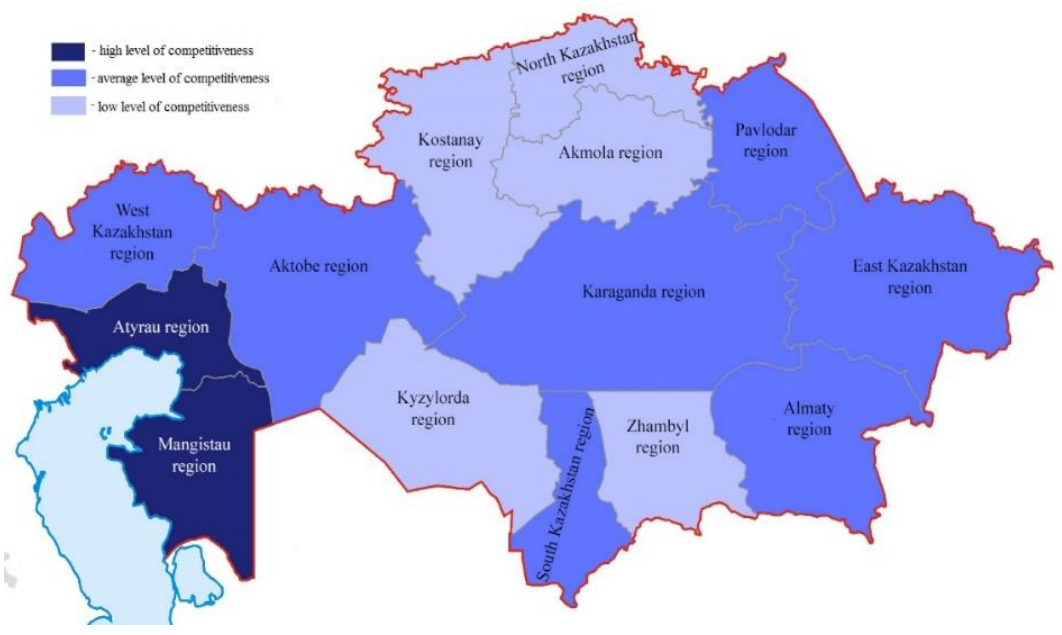

Fig. 3. Map of Kazakhstan's regional competitiveness, 2018

Almaty regions. Almost all the northern regions (North Kazakhstan, Akmola, Kostanay regions) and two southern regions (Zhambyl, Kyzylorda regions) show a low level of competitiveness in comparison with other regions. Although all these regions have a significant competitive advantage - suitable conditions for the development of agriculture and the creation of the agro-industrial complex, this industry is not developed at the proper level.

The competitiveness of any economic entity should be studied in dynamics, that is, competitiveness is formed only when there is a positive trend in the development of indicators. To assess the development trend of the regions of Kazakhstan, each indicator has been calculated over the past 5 years and an aggregated regional competitiveness index has been obtained.

Table 2. Regional competitiveness index of Kazakhstan for 2014-2018

\begin{tabular}{|c|c|c|c|c|c|c|c|c|c|c|}
\hline \multirow[b]{2}{*}{ Region } & \multicolumn{2}{|c|}{2018} & \multicolumn{2}{|c|}{2017} & \multicolumn{2}{|c|}{2016} & \multicolumn{2}{|c|}{2015} & \multicolumn{2}{|c|}{2014} \\
\hline & 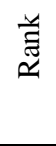 & $\underset{\Xi}{\stackrel{\varpi}{\Xi}}$ & 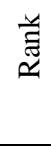 & $\stackrel{凶}{\stackrel{\varpi}{\Xi}}$ & 華 & $\underset{\Xi}{\stackrel{\varpi}{\Xi}}$ & 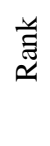 & $\underset{\Xi}{\overparen{\Xi}}$ & 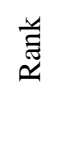 & $\underset{\Xi}{\stackrel{\varpi}{\Xi}}$ \\
\hline Almaty city & 1 & 80,05 & 1 & 79,5 & 1 & 81,65 & 1 & 77,57 & 1 & 78,3 \\
\hline Atyrau region & 2 & 70,71 & 2 & 70,59 & 2 & 69,93 & 2 & 70,94 & 2 & 71,26 \\
\hline Nur-Sultan city & 3 & 67,62 & 3 & 65,24 & 3 & 69,83 & 3 & 64,51 & 3 & 62,86 \\
\hline Mangistau region & 4 & 54,51 & 4 & 50,45 & 4 & 52,34 & 4 & 54,96 & 4 & 52,24 \\
\hline Karaganda region & 5 & 47,51 & 5 & 45,76 & 5 & 45,16 & 5 & 46,21 & 5 & 46,5 \\
\hline $\begin{array}{l}\text { East Kazakhstan } \\
\text { region }\end{array}$ & 6 & 43,73 & 6 & 42,37 & 6 & 42,04 & 7 & 42,87 & 8 & 42,75 \\
\hline $\begin{array}{l}\text { West Kazakhstan } \\
\text { region }\end{array}$ & 7 & 42,35 & 7 & 41,31 & 7 & 40,81 & 6 & 43,2 & 6 & 43,29 \\
\hline Pavlodar region & 8 & 41,92 & 9 & 40,1 & 9 & 40,61 & 9 & 41,25 & 9 & 42,18 \\
\hline $\begin{array}{l}\text { South Kazakhstan } \\
\text { region }\end{array}$ & 9 & 41,18 & 8 & 40,32 & 8 & 40,73 & 10 & 41 & 10 & 41,38 \\
\hline Aktobe region & 10 & 40,65 & 10 & 39,72 & 11 & 39,41 & 8 & 41,57 & 7 & 43,03 \\
\hline
\end{tabular}




\begin{tabular}{l|c|c|c|c|c|c|c|c|c|c} 
Almaty region & 11 & 40,26 & 11 & 38,95 & 10 & 39,61 & 11 & 40,19 & 11 & 40,39 \\
\hline Kostanay region & 12 & 38,17 & 12 & 36,38 & 12 & 36,95 & 12 & 37,34 & 13 & 38,02 \\
\hline Akmola region & 13 & 36,75 & 13 & 35,39 & 14 & 34,78 & 14 & 35,4 & 14 & 35,22 \\
\hline Kyzylorda region & 14 & 35,42 & 14 & 34,78 & 13 & 35,13 & 13 & 36,81 & 12 & 38,64 \\
\hline $\begin{array}{l}\text { North Kazakhstan } \\
\text { region }\end{array}$ & 15 & 33,56 & 16 & 32,07 & 15 & 33,34 & 16 & 32,73 & 16 & 33,38 \\
\hline Zhambyl region & 16 & 33,32 & 15 & 32,59 & 16 & 33,22 & 15 & 33,61 & 15 & 33,49 \\
\hline
\end{tabular}

Note - compiled by the authors on the basis of calculations

According to table 2, the top 5 regions of Kazakhstan over the past 5 years have not changed. 5 years is a short time to formulate certain conclusions, but we can say that these regions have the potential for sustainable growth.

Over the past 5 years, the East Kazakhstan region has risen two positions in the regional competitiveness rating. In the region, within the framework of the program of industrial and innovative development for 2015-2018, 19 projects have been implemented and 3,500 new jobs have been created, and the tourism infrastructure is actively developing as part of the state tourism development program.

The Aktobe region, on the contrary, lost its competitive position and went down in the ranking from $7^{\text {th }}$ to $10^{\text {th }}$ place. This is due to the negative migration balance in the region, the economically active population is leaving the region, and their number is growing every year.

The outsiders in this rating are the North Kazakhstan and Zhambyl regions. In these regions, compared with other very few operating enterprises, and in particular enterprises carrying out R\&D (for comparison, in Almaty - 131, in the East Kazakhstan region - 34, in the Zhambyl region - 11, in the North Kazakhstan region - 5). As a result, there are low level of gross regional product and average wages.

\section{Conclusion}

Almost all the problems of economic development of Kazakhstan can be associated with omissions in regional development: a high degree of inequality, uneven development of innovations and infrastructure, uneven growth rates, levels of productivity and employment, differences in the level of education. Therefore, it is important to assess the potential of each region.

The purpose of this article was to create a method for assessing the competitiveness of the regions of Kazakhstan and, using this method, build a rating of regional competitiveness. The rating of regions showed heterogeneous development of regions and a sharp difference in growth rates between regions. For this reason, centralized regional development measures are ineffective. In Kazakhstan, it is necessary to move from centralized to regional development measures, with effective coordination, so that each region has its own development strategy with emphasis on their competitive advantages. To do this, it is advisable to conduct a detailed review of the regions, to identify comparative advantages, in order to help them determine the most suitable direction of development.

\section{References}

1. E. Birnie, R. Johnston, L. Heery, E. Ramsey, Regional Studies 53(10), 1494-1504 (2019)

2. M. Kitson, R. Martin, P. Tyler, Regional Studies 38(9) (2004)

3. R. Wokoun, N.M. Krejcova, 16th International Colloquium on Regional Sciences (2013) 
4. European Comission, European Competitiveness Report, Enterprise and Industry Publications. European Communities, Brussels (2004)

5. I. Turok, Regional Studies 29(8), 1069-1083 (2003)

6. D. Alexa, L.M. Cismas, A.V. Rus, M.L. Pop Silaghi, Economic Computation and Economic Cybernetics Studies and Research 53(1), 107-124 (2019)

7. L. Dijkstra, P. Annoni, EU regional competitiveness index, Publications Office, Luxembourg (2013)

8. E. Koisova, E. Grmanova, K. Skrovankova, J. Kostrova, Engineering Economics 30(2), 203-210 (2019)

9. R. Boschma, Regional Studies 38(9), 1001-1014 (2004)

10. P. Kresl, D. Ietri, Urban Competitiveness: Theory and Practice, 1st edition, London: Routledge (2014)

11. Y.M. Holis, I. Syabri, H. Prabatmojo, The 4th PlanoCosmo International Conference IOP Publishing IOP Conf. Series: Earth and Environmental Science 158 (2018)

12. Z. Temerbulatova, B. Mukhamediyev, G. Sadykhanova, P.Salibekova, Proceedings of the 33rd International Business Information Management Association Conference, 4918-4926 (2019)

13. R. Huggins, Regional Studies 37(1), 89-96 (2003)

14. U. Bronisz, W. Heijman, A. Miszczuk, Jahrbuch für Regionalwissenschaft 28(2), 133$143(2008)$

15. AV-Group Consortium http://av-group.ru/av-strategy/av-rci/

16. Official website of the Statistics Committee of the Ministry of National Economy of the Republic of Kazakhstan http://stat.gov.kz/ 